\title{
MODEL PENDIDIKAN BERWAWASAN KEBANGSAAN BAGI ANAK USIA DINI SEBAGAI SARANA INTEGRASI BANGSA
}

\author{
Ubaidillah $^{\text {a,1 }}$ \\ a Sekolah Tinggi Agama Islam Daruttaqwa \\ 1 lubaydays@gmail.com
}

\section{Informasi artikel}

Received :

Agust 15, 2018.

Revised :

Agust 27, 2018.

Publish :

September 09, 2018.

Kata kunci:

Model Pendidikan;

Wawasan Nusantara;

Intregasi Bangsa;

\section{Keywords:}

Educational Model;

Nusantara Insight;

Nation Integration;

\begin{abstract}
ABSTRAK
Pendidikan Anak Usia Dini (PAUD) merupakan salah satu hal terpenting dalam membangun masa depan seseorang. Sehingga mereka sangat tepat jika dijadikan komunitas awal pembentukan karakter bangsa. Salah satu cara agar anak dapat menerima materi pelajaran adalah melalui permainan. Permainan tersebut diantaranya adalah permainan tradisional. model pendidikan berwawasan kebangsaan dalam pendidikan anak usia dini menggunakan pendekatan tematik, jadi melalui tema inilah berbagai macam potensi anak dapat di kembangkan, nilai-nilai kebangsaan yang ingin disosialisasikan dan ditransformasikan dalam kegiatan pembelajaran secara terpadu mengembangkan kemampuan, fisik motori, keterampilan (motorik halus), kognitif, sains, seni, bahasa dan pembiasaan, dengan menggunakan kegiatan-kegiatan pembelajaran yang dirancang dengan konsep belajar sambil bermain.
\end{abstract}

ABSTRACT
Early Childhood Education (PAUD) is one of the most important things
in building one's future. So they are very appropriate if used as an initial
community formation of national character. One way for children to
receive learning material is through games. These games include
traditional games. nationalism-oriented education model in early
childhood education uses a thematic approach, so through this theme
various kinds of children's potential can be developed, national values
that want to be socialized and transformed in learning activities in an
integrated manner developing abilities, physical motori, skills (fine
motor skills), cognitive, science, art, language and habituation, using
learning activities that are designed with the concept of learning while
playing

This work is licensed under a Creative Commons Attribution-ShareAlike 4.0 International License. Allows readers to read, download, copy, distribute, print, search, or link to the full texts of its articles and allow readers to use them for any other lawful purpose. 


\section{PENDAHULUAN}

Berdasarkan sudut pandang medis-neurologis, psikososiokultural, dan edukatif, Pendidikan Anak Usia Dini (PAUD) merupakan hal yang sangat esensial. PAUD sangat berpengaruh terhadap pertumbuhan struktur dan fungsi otak anak sehingga dapat memberikan pengaruh yang menetap terhadap perkembangan perilaku dan kepribadian anak selanjutnya. Perkembangan anak usia dini telah memberikan berbagai informasi, bahwa masa kanak-kanak sebagai salah satu tahap perkembangan manusia yang memiliki karakteristik tersendiri. Pendidikan yang berorientasi kepada perkembangan memungkinkan pendidik untuk merencanakan berbagai pengalaman yang dapat menumbuhkan minat anak usia dini dan merangsang keingintahuan mereka. PAUD adalah investasi yang sangat besar bagi keluarga dan juga bangsa. Merekalah yang kelak membangun bangsa supaya tidak tertinggal dari bangsa-bangsa lain (Suyanto, 2005:2).

Usia 0-8 tahun merupakan usia emas (golden age) anak usia dini (early childhood), sehingga mereka sangat tepat jika dijadikan komunitas awal pembentukan karakter bangsa. Para ahli menyimpulkan bahwa keberhasilan pada masa ini akan menentukan masa depan anak itu sendiri. Para ahli menyimpulkan bahwa keberhasilan pada masa ini akan menentukan masa depan anak itu sendiri dan keberhasilan ini tentunya akan terkait dengan masa depan bangsa. Pendidikan berwawasan kebangsaan pada anak usia dini diharapkan dapat mempersiapkan mereka kelak sebagai manusiamanusia yang mempunyai identitas di dalam masyarakat lokalnya sekaligus mempunyai visi global untuk membangun dunia bersama dalam budaya global. Pertanyaan apakah pendidikan wawasan kebangsaan dapat diberikan untuk anak usia 
dini? Jerome Bruner menyatakan setiap materi dapat diajarkan kepada setiap kelompok umur dengan cara-cara yang sesuai dengan perkembangannya. Pada anak usia dini, kuncinya adalah pada permainan. Permainan adalah merupakan kata kunci pada pendidikan anak usia dini. Permainan anak sebenarnya mengacu pada kebersamaan, gotong royong, berteman dan mengurangi rasa egois anak. Hal ini akan nampak pada saat mereka bermain selalu memerlukan "partner", walaupun dalam partner tersebut bisa jadi mereka bersaing. Lebih-lebih pada permainan tradisional, sifat kebersamaan ini akan nampak. Hal ini berbeda dengan permainan dalam bentuk digital yang lebih bersifat individu. Misalnya dalam permainan Play Station, mereka cukup sendirian saja, berhadapan dengan komputer atau sejenisnya. Untuk mengatasi hal tersebut diperlukan alat permainan yang membangun "pertemanan", di antara anak-anak. Permainan mengembangkan aspek "humanisasi" anak dan sekaligus ditujukan untuk pendidikan wawasan kebangsaan.

Pendidikan wawasan kebangsaan bagi anak usia dini saat ini mendapat saingan yang berat yakni alat permainan yang datangnya dari negara lain. Anak-anak selama ini bermain dengan robot, boneka-boneka bule, dan rumah bergaya Eropa. Akibatnya ia akan membangun konsep diri tentang robot, manusia, dan rumah dari alat permainan tersebut. Tanpa disadari, ia menjadi suka pada pahlawan-pahlawan robot dari luar, orang bule dan rumah bergaya Eropa. Anak yang suka mainan Spiderman, Spongebob, atau Barbie, akan mengkoleksi dan menggunakan benda-benda: kartu-kartu, baju dan aksesoris bertema Spiderman, Spongebob atau Barbie, minta dibacakan buku dan melihat film Spiderman, Spongebob atau Barbie. Akibatnya konsep anak akan mencontoh karakter yang ada di dunia bermain yang berasal dari luar negeri. Hal ini sangat ironi karena tanpa sadar kita ikut andil dalam proses penjajahan budaya tersebut 
dan membentuk karakter anak kita menjadi mirip dengan mainan, buku, baju dan film yang menjadi kesukaannya.

PAUD-PAUD di Indonesia mengadopsi sistem kegiatan bermain dari negara maju misalnya Amerika, Singapura, Australia atau dari negara lain. Kemudian menerapkan sama dengan negara asalnya dengan harapan akan meningkatkan mutu PAUD-nya. Lebih ironi lagi apabila tema-tema yang digunakan dalam kegiatan bermain juga di adopsi dari luar, melestarikan budaya-budaya negara lain seperti Hallowen, Valentine's Day, Pirate, Season, dan lain sebagainya. Oleh karena itu dengan penyusunan artikel ini diharapkan dapat merubah (melakukan perubahan) dengan menanamkan wawasan kebangsaan dalam kegiatan bermain, melalui integrasi unsur-unsur budaya Indonesia dalam kegiatan bermain dan alat permainan edukatif yang digunakan oleh anak usia dini. Mayke Sugianto, secara umum mencoba menghubungkan antara bentuk permainan atau kegiatan dengan aspek yang dikembangkan, antara lain sebagai berikut :

1) Permainan untuk perkembangan persepsi-motor (seperti lateralisasi, koordinasi mata dan tangan) antara : musik, ritme lari, lompat, manipulasi benda, bermain drama.

2) Permainan spasial (posisi, pengukuran, jarak) antara lain: balok, mengecat, kegiatan motorik, menggabungkan keping.

3) Permainan latar bentuk (Figure-Ground), visual, auditif, taktil seperti menyusun puzzle, mengecat, musik, lukisan.

4) Permainan untuk perkembangan kemampuan memahami elemen/bagian dari keseluruhan dan sebaliknya (Whole-Part) seperti memisah dan menyatukan kembali. 
5) Perminan klasifikasi (mengelompokkan berdasarkan ukuran, warna, bentuk dan lainlain) seperti memilih dan memadamkan.

6) Mengurutkan (Sequence), yaitu seriasi, menduga urutan dalam ukuran, warna, bentuk dan lain-lain.

7) Permainan untuk perkembangan, kesadaran akan tanda (Clue Awareness) dan menggunakannya dalam pemecahan masalah, misalnya kegiatan mencari apa yang tersembunyi, menyatukan benda-benda (Sugianto, 1995:20).

Montessori berpendapat bahwa lingkungan yang paling tepat bagi anak adalah bermain. Bermain pada anak-anak mempunyai arti yang sangat penting, karena melalui bermain, anak mengalami perkembangan dalam segala aspek kehidupannya (Anggani 1992:35). Bahkan antara "bermain dan anak" tidak dapat dipisahkan satu sama lain. Hak untuk memperolah kesempatan bermain dan berkreasi telah dinyatakan secara tegas oleh PBB dalam salah satu deklarasi hak anak (Unicef, 1990:18).

Piaget menegaskan, seorang yang terkenal dalam bidang kognitif menyatakan bahwa permainan mengembangkan intelektual anak, karena dalam bermain terjadi tambahan pengetahuan baru dari obyek yang tidak terdapat dalam struktur kognitifnya (Suyanto, 2005:52).

Paham kebangsaan bagi bangsa Indonesia merupakan suatu paham yang menyatukan berbagai suku bangsa dan pelbagai keturunan bangsa asing dalam wadah kesatuan Negara Republik Indonesia. Dalam konsep ini berarti tinjauannya adalah formal yaitu kesatuan dalam arti kesatuan rakyat yang menjadi warga Negara Indonesia, yang disebut dengan Nasionalisme Indonesia. Oleh karena rakyat Indonesia ber-Pancasila, maka nasionalisme Indonesia disebut juga dengan nasionalisme Pancasila, yaitu paham kebangsaan yang berdasar nilai-nilai Pancasila. 
Untuk memahami kebangsaan Indonesia, secara sistemik menjelaskan dengan mengacu pada sila ketiga Pancasila : Persatuan Indonesia. Istilah persatuan berasal dari kata satu, yang berarti utuh tidak terpecah belah. Persatuan berarti sifat-sifat dan keadaan yang sesuai dengan hakekat satu, yang mengandung pengertian disatukannya bermacam-macam bentuk menjadi satu kebulatan atau dengan kata lain diartikan juga usaha untuk menjadikan keseluruhan ke arah satu kesatuan yang tidak terpisahkan. Dari dua pengertian itu dapat dikatakan persatuan adalah proses ke arah bersatu.

Di dalam persatuan ini harus ada sesuatu hal sebagai ciri pembeda yang dapat menghimpun bermacam-macam hal menjadi satu kesatuan. Sebagai contoh persatuan sepak bola, sesuatu hal yang dapat menghimpunnya adalah keahlian dalam hal bermain bola. Adanya keahlian inilah, mereka yang dari bermacam-macam anggota dapat dihimpun menjadi satu kesatuan yang erat hubungannya antara satu dengan yang lain. Demikian dalam hal kenegara an, yang dapat menghimpunnya menjadi satu kesatuan adalah adanya keinginan hidup bersama dalam satu negara. Persatuan merupakan suatu proses atau usaha, sedangkan tujuannya adalah kesatuan.

Wawasan kebangsaan apabila dibawa ke masalah kenegara an bukanlah kebangsaan atas dasar asal keturunan, yang dalam arti: sejarah yang sama, nasib yang sama dan kehendak yang sama, karena hal yang demikian ini tidak dapat diterapkan dalam negara -negara sekarang. Karena negara -negara sekarang memasukkan juga kelompok manusia lain yang tidak sama sejarahnya dan tidak sama nasibnya. Sebagai contoh rakyat Timor-Timur mereka tidak sama sejarah dan sama nasibnya, tetapi mereka pernah bersatu sebagai bangsa Indonesia. Oleh karena itu hanya diartikan dengan mempunyai cita-cita yang sama menjadi satu kesatuan sebagai warga negara. Kesatuan dalam satu negara ini bukan secara alami, tetapi satu kesatuan yang 
dibentuk Jadi kebangsaannya secara buatan atau kebangsaan negara yang lebih popular dengan sebutan istilah nasionalisme, untuk membedakan kebangsaan secara alami. Nasionalisme inilah yang dituju oleh persatuan. Jadi persatuan merupakan proses, sedangkan tujuannya adalah nasionalisme (kesatuan dalam negara).

Rumusan Persatuan Indonesia adalah dalam artian politik, karena yang menyesuaikan dengan hakekat satu atau yang dapat menjadikan dirinya ke arah satu kesatuan adalah manusia, yang ditegaskan di sini dalam arti rakyat Indonesia, yang diusahakan menjadi satu kesatuan yang lambat laun menjadi bangsa Indonesia dalam arti bangsa Negara . Dari uraian-uraian di atas, pendidikan berwawasan kebangsaan sebagai sarana integrasi bangsa berarti rasa kesatuan yang tumbuh dalam hati sekelompok manusia berdasarkan cita-cita yang sama dalam satu ikatan organisasi kenegara an Indonesia. Persatuan Indonesia adalah proses untuk menuju terwujudnya nasionalisme Indonesia.

Pendidikan Berwawasan Kebangsaan pada anak usia dini dikhususkan untuk anak-anak TK di kawasan pesisir pantai. Beberapa pertimbangan yang dapat diberikan adalah sebagai berikut:

1. Taman Kanak-Kanak termasuk anak-anak usia $4-6$ tahun yang memiliki kemampuan memahami pengetahuan yang kompleks dibandingkan anak usia dini yang ada pada lembaga Taman Penitipan Anak, Taman Bermain (Play Group), atau pos PAUD yang ada di desa. Pendidikan Wawasan Kebangsaan berkaitan dengan kehidupan berbangsa yang ruang cakupannya lebih luas dari ruang hidup anak usia 0- 3 tahun, yaitu lingkup keluarga.

2. Kawasan pesisir dipilih karena karakteristik negara -bangsa Indonesia adalah Negara kepulauan yang dikelilingi oleh laut. Oleh karena itu pengenalan tentang 
kondisi geografis dengan segala isinya menjadi penting dipahami oleh semua anak usia dini khususnya yang hidup di lingkungan laut.

Wawasan kebangsaan Indonesia adalah wawasan nusantara. Wawasan nusantara adalah cara pandang bangsa Indonesia tentang diri dan lingkungannya berdasarkan ide nasionalnya yang dilandasi Pancasila dan UUD 1945, yang merupakan aspirasi bangsa yang merdeka, berdaulat, bermartabat, serta menjiwai tata hidup dan tindak kebijaksanaannya dalam mencapai tujuan nasional. Wawasan nusantara adalah cara pandang, cara memahami, cara menghayati, cara bersikap, cara berpikir, cara bertindak, cara bertingkah laku bangsa Indonesia sebagai interaksi proses psikologis, sosiokultural, dengan aspek astagatra (kondisi geografis, kekayaan alam, dan kemampuan serta ideologi, politik, ekonomi, sosial, budaya dan hankam). Hakikat wawasan nusantara adalah cara pandang bangsa Indonesia tentang bhineka tunggal ika. Bhineka Tungal Ika yaitu beraneka ragam tetapi satu jua.

Indonesia merupakan negara multikultural. Multikulturalisme merupakan konsep di mana komunitas dal am konteks kebangsaan dapat mengakui keberagaman, perbedaan, dan kemajemukan budaya, ras, suku, etnis, dan agama. Sebuah konsep yang memberikan pemahaman bahwa sebuah bangsa yang plural dan majemuk adalah bangsa yang dipenuhi dengan budaya-budaya yang beragam atau multikultural. Bangsa yang multikultural adalah bangsa yang kelompok-kelompok etnik atau budaya (ethnic and cultural groups)-nya yang ada dapat hidup berdampingan secara damai dalam prinsip co-existensi yang ditandai oleh kesediaan untuk menghormati budaya lain.

Nasionalisme dalam masyarakat multikultural yang dituju adalah persatuan. Nasionalisme berarti rasa kesatuan yang tumbuh dalam hati sekelompok manusia 
berdasarkan cita-cita yang sama dalam satu ikatan. Untuk mempertahankan dan memperkuat nasionalisme Indonesia, setiap warga negara wajib melakukan bela negara dan cinta tanah air. Bela negara merupakan upaya penyadaran bahwa setiap warga negara memiliki tugas dan tanggung jawab untuk membela kepentingan nasional demi menjaga keutuhan negara . Bela negara tidak harus diartikan angkat senjata melawan musuh, tetapi berjuang sesuai dengan kemampuan dan bidang profesi yang digelutinya. Cinta tanah air adalah sikap, perilaku, dan ikatan perasaan yang selalu ingin menjalin hubungan baik dengan sesame warga negara, lingkungan serta budaya dari suatu negara / bangsa terrtentu, bertanggung jawab dan memelihara budaya, alam, dan tatanan hidup yang baik di negerinya, peduli terhadap kawasan, kedaulatan, lingkungan alam, budaya, serta martabat bangsa dan negara.

Indonesia merupakan suatu kesatuan wilayah laut yang di dalamnya terdapat ribuan pulau. Keanekaragamaan Indonesia meliputi kondisi geografi yang berupa negara kepulauan yang berisi dengan keanekaragaman sumber daya alam : flora, fauna, dan mineral dan gas, dan beraneka suku bangsa yang mendiami dari Sabang sampai Merauke. Selain itu keanekaragaman dari aspek agama, sosial-budaya, dan bahasa. Keanekaragaman yang ada merupakan mozaik yang membentuk bangunan kesatuan yaitu bangsa Indonesia. Oleh karena itu memahami bangsa Indonesia harus memahami tentang mozaik keanekaragaman yang membentuk sebuah kesatuan.

\section{Rumusan Masalah}

1. Bagaimana model pendidikan berwawasan nusantara bagi Anak Usia Dini sebagai sarana intregasi bangsa ?

2. Apa dampak model pendidikan berwawasan nusantara bagi Anak Usia Dini sebagai sarana intregasi bangsa ? 


\section{Tujuan Penulisan}

Tujuan artikel ini yakni agar menambah pengetahuan tentang model pendidikan berwawasan nusantara serta mengetahui dampak model pendidikan berwawasan nusantara bagi anak usia dini sebagai sarana intregasi bangsa, hal ini bertujuan untuk merubah (melakukan perubahan) dengan menanamkan wawasan kebangsaan dalam kegiatan bermain melalui intregasi unsur-unsur budaya Indonesia dalam kegiatan bermain dan alat permainan edukatif yang digunakan anak usia dini sehingga memberikan dampak yang positif bagi perkembangan anak usia dini.

\section{Metode Literatur}

Dalam artikel ini penulis menggunakan metode literatur. Penulis menggunakan berbagai macam sumber pustaka dari internet yang menjelaskan tentang model pendidikan berwawasan kebangsaan. Berbagai macam sumber referensi yang ada menjadikan penulisan artikel ini berjalan dengan baik.

\section{PEMBAHASAN}

1. Model Pendidikan Berwawasan Nusantara Bagi Anak Usia Dini Sebagai Sarana Intregasi Bangsa

a. Pengertian model pendidikan

Model - model pendidikan adalah beberapa cara atau teknik yang digunakan oleh guru kepada siswa dalam menyajikan materi pembelajaran dalam sebuah proses pembelajaran agar tujuan pembelajaran yang sudah dirancang dapat tercapai. Beberapa model pembelajaran ini diterapkan guru saat mengajarkan sesuatu kepada muridnya dengan tujuan agar pesan dari materi pembelajaran itu sendiri tersampaikan dengan mudah. Model pembelajaran yang sudah ada sejauh ini terbukti bisa sangat membantu 
pekerjaan para guru dikarenakan para siswa dapat mengerti, tahu, dan paham sebuah pelajaran dengan lebih mudah .

Jika membahas tentang beberapa contoh dari model-model pembelajaran itu sendiri, ada beberapa model yang sudah tidak asing lagi dengan kita, namun beberapa diantaranya juga merupakan model baru yang baru diterapkan dalam dunia pendidikan.

Beberapa contoh model pembelajaran yang sudah umum diketahui yaitu :

1) metode ceramah

2) diskusi

3) studi kasus

4) demonstrasi

Sedangkan beberapa model pembelajaran yang masih terbilang asing tidak lain adalah Contextual Teaching and Learning (CTL), Pembelajaran kontekstual (Contextual Teaching and Learning) adalah konsep belajar yang membantu guru mengaitkan antara materi yang diajarkan-nya dengan situasi dunia nyata siswa dan mendorong siswa membuat hubungan antara pengetahuan yang dimilikinya dengan penerapannya dalam kehidupan mereka sehari-hari, dengan melibatkan tujuh komponen utama pembelaaran efektif, yakni: konstruktivisme (constructivism), bertanya (questioning), menemukan (inquiri), masyarakat belajar (learning community), pemodelan (modeling), dan penilaian sebenarnya (authentic assessment), Cooperative Learning (CL), Cooperative Learning adalah suatu strategi belajar mengajar yang menekankan pada sikap atau perilaku bersama dalam bekerja atau membantu di antara sesama dalam struktur kerjasama yang teratur dalam 
kelompok, yang terdiri dari dua orang atau lebih. Dimana pada tiap kelompok tersebut terdiri dari siswa-siswa berbagai tingkat kemampuan, melakukan berbagai kegiatan belajar untuk meningkatkan pemahaman mereka tentang materi pelajaran yang sedang dipelajari. Setiap anggota kelompok bertanggung jawab untuk tidak hanya belajar apa yang diajarkan tetapi juga untuk membantu rekan belajar, sehingga bersama-sama mencapai keberhasilan. Semua Siswa berusaha sampai semua anggota kelompok berhasil memahami dan melengkapinya. Model pembelajaran kooperatif dikembangkan untuk mencapai setidak-tidaknya tiga tujuan pembelajaran yaitu Hasil belajar akademik, penerimaan terhadap perbedaan individu, dan pengembangan keterampilan sosial. Prinsip model pembelajaran kooperatif yaitu : 1) saling ketergantungan positif; 2) tanggung jawab perseorangan; 3) tatap muka; 4) komunikasi antar anggota; dan 5) evaluasi proses kelompok.

Problem Based Learning (PBL), Problem-Based Learning (PBL) atau Pembelajaran Berbasis Masalah (PBM) adalah metode pembelajaran yang mendorong siswa untuk mengenal cara belajar dan bekerjasama dalam kelompok untuk mencari penyelesaian masalah-masalah di dunia nyata. Simulasi masalah digunakan untuk mengaktifkan keingintahuan siswa sebelum mulai mempelajari suatu subyek. PBL menyiapkan siswa untuk berpikir secara kritis dan analitis, serta mampu untuk mendapatkan dan menggunakan secara tepat sumber-sumber pembelajaran. Sehingga dapat diartikan bahwa PBL adalah proses pembelajaran yang titik awal pembelajaran berdasarkan masalah dalam kehidupan nyata lalu dari masalah ini siswa dirangsang untuk mempelajari masalah berdasarkan pengetahuan 
dan pengalaman yang telah mereka punyai sebelumnya (prior knowledge) sehingga dari prior knowledge ini akan terbentuk pengetahuan dan pengalaman baru.

Pembelajaran bersiklus (Cycle Learning), pembeajaran bersiklus atau Learning Cycle adalah suatu model pembelajaran yang berpusat pada siswa (student centered). Ciri khas model pembelajaran Learning Cycle ini adalah setiap siswa secara individual belajar materi pembelajaran yang sudah dipersiapkan guru yang kemudian hasil belajar individual dibawa ke kelompok-kelompok untuk didiskusikan oleh anggota kelompok, dan semua anggota kelompok bertanggung jawab atas keseluruhan jawaban sebagai tanggung jawab bersama.

\section{Realistic Mathematic Education (RME), Pendekatan Realistic} Mathematic Education (RME) adalah suatu pendekatan yang menempatkan realitas dan pengalaman siswa sebagai titik awal pembelajaran dimana siswa diberi kesempatan untuk mengkonstruksi sendiri pengetahuan matematika formalnya melalui masalah-masalah realitas yang ada

Open Ended (OE) Pada pendekatan open-ended masalah yang diberikan adalah masalah yang bersifat terbuka (open-ended problem) atau masalah tidak lengkap (incomplete problem) masalah sebelumnya (asli). Dasar keterbukaan masalah diklasifikasikan dalam tiga tipe, yakni:

1) Prosesnya terbuka, maksudnya masalah itu memiliki banyak cara penyelesaian yang benar

2) Hasil akhirnya terbuka, maksudnya masalah itu memiliki banyak jawaban yang benar 
3) Cara pengembangan lanjutannya terbuka, maksudnya ketika siswa telah menyelesaikan masalahnya, mereka dapat mengembangkan masalah baru yaitu dengan cara mengubah kondisi masalah sebelumnya (asli).

Dari sekian banyak model pembelajaran yang sudah disebutkan di atas, tidak ada satupun yang bisa dianggap sebagai model pembelajaran terbaik. Hal itu dikarenakan setiap model pembelajaran yang diterapkan oleh seorang tenaga pendidik selalu saja disertai dengan kelebihan dan kekurangan. Para tenaga pendidik bisa memilih beberapa metode yang dianggap cocok dengan kondisi kelas yang mereka tangani dan materi yang akan diberikan, bukan lantas memilih metode yang menurutnya paling baik dan menerapkannya di kelas terus menerus karena tidak semua metode akan cocok dengan materi yang disampaikan.

b. Model pendidikan berwawasan kebangsaan bagi anak usia dini

Model Pendidikan Berwawasan Kebangsaan dalam pembelajaran anak usia dini menggunakan pendekatan tematik karena mengacu pada model pembelajaran di TK yang bersifat tematik. Melalui payung tema inilah berbagai macam potensi anak, misalnya fisik motorik, ketrampilan (motorik halus), kognitif, sains, bahasa, seni, soaia dan emosonal, serta nilai-nilai keagamaan, moral, dan nilai-nilai kebangsaan secara integral-komprehensif dikembangkan. Jadi melalui satu tema yang dilakukan dalam kegiatan pembelajaran semua potensi anak dapat dikembangkan. Oleh karena itu nilainilai kebangsaan yang ingin disosialisasikan dan ditransformasikan dalam kegiatan pembelajaran. secara terpadu mengembangkan kemampuan fisik 
motorik, ketrampilan (motorik halus), kognitif, sains, seni, bahasa, dan pembiasaan.

Tema-tema (sub tema-sub tema) kegiatan pembelajaran merupakan materi (bahan ajar) yang disampaikan kepada anak-anak. Materi (bahan ajar) secara integratif (terpadu) dengan kegiatan-kegiatan pembelajaran yang dirancang dengan konsep belajar sambil bermain, sehingga anak-anak tidak merasa diceramahi atau dinasehati secara langsung. Agar konsep belajar sambil bermain dan bermain sambil belajar terwujud, maka berbagai metode pembelajaran digunakan dalam kegiatan pembelajaran ini, yaitu: eksperimen (uji coba), bermain peran, ceritera, tanya-jawab, percakapan, penugasan (mengerjakan Lembar Kerja Anak, menggambar, melipat, mengecap (membatik), usap-abur, menempel, kolase).

Bahan ajar merupakan seperangkat materi/substansi pelajaran (teaching material) yang disusun secara sistematis, menampilkan sosok utuh dari kompetensi yang akan dikuasai oleh peserta didik dalam kegiatan pembelajaran. Dick dan Carey, mengajukan hal-hal berikut dalam pembuatan bahan ajar: (1) memperhatikan motivasi belajar yang diinginkan, (2) kesesuaian materi yang diberikan, (3) mengikuti suatu urutan yang benar, (4) berisikan informasi yang dibutuhkan, dan (5) adanya latihan praktek, (6) dapat memberikan umpan balik, (7) tersedia tes yang sesuai dengan materi ajar, (8) tersedia petunjuk untuk tindak lanjut, (9) tersedia petunjuk bagi peserta didik untuk tahap-tahap aktivitas yang dilakukan, (10) dapat diingat dan ditransfer. 
Bahan ajar yang efektif harus memenuhi syarat sebagai berikut : (1) ketepatan kognitif, (2) tingkat berpikir siswa, (3) biaya, (4) ketersediaan bahan, dan (5) mutu teknis. Dalam pembuatan bahan ajar hendaknya mempertimbangkan empat aspek, yaitu (1) aspek akademik, (2) aspek sosial, (3) aspek rekreasi, dan (4) aspek pengembangan pribadi. Bahan ajar yang menjadi target penelitian ini, adalah alat permainan edukatif tradisional yang akan dimodifikasi, namun tidak lepas dari pakem edukatifnya. Bahan ajar pendidikan wawasan kebangsaan yang akan dibuat, bertujuan untuk mengukir cinta tanah air melalui proses knowing the good, loving the good, and acting the good, proses pendidikan yang melibatkan aspek kognitif, emosi, dan fisik, sehingga cinta tanah air bisa terukir menjadi habit of the mind, heart, and hands.

Berikut ini dipaparkan beberapa pertimbangan Pendidikan Wawasan Kebangsaan diberikan pada Anak Usia Dini, yaitu:

1) Usia dini merupakan "masa keemasan" dalam pengembangan seluruh potensi yang dimiliki seorang anak. Penddikan tentang wawasan kebangsaan yang berisi nilai-nilai persatuan-kesatuan, toleransi, menghargai perbedaan, penghargaan terhadap Hak Asasi Manusia, tolong-menolong, cinta tanah air, bela negara, gotong-royong, musyawarah, mencintai lingkungan, perpandangan jauh ke depan (visioner), dan keadilan. Kesemua nilai ini akan terlekat dalam kehidupan anak sampai mereka tumbuh menjadi warga bangsa yang dewasa. 
2) Dunia anak adalah dunia bermain. Bermain untuk anak sesungguhnya sebuah proses belajar. Anak-anak belajar nilai-nilai kebangsaan melalui pengalaman bermain. Dengan suasana yang menyenangkan dan rekreatif nilai-nilai kebangsaan disosialisasikan dan ditransformasikan kepada anak, sehingga proses pendidikan yang dilaksanakan tidak bersifat indoktrinasi atau pemaksaan.

3) Amanat Undang - Undang No. 20 Tahun 2003 tentang Sistem Pendidikan Nasional (Pasal 3) menyatakan bahwa tujuan pendidikan nasional adalah berkembangnya potensi peserta didik agar menjadi manusia yang beriman dan bertaqwa kepada Tuhan Yang Maha Esa. Berakhlak mulia, sehat, berilmu, cakap, mandiri, dan menjadi warga negara yang demokratis serta bertanggung-jawab. Tujuan pendidikan nasional ini seharusnya dimulai sejak dini melalui pendidikan anak usia dini khususnya di Taman Kanak-Kanak

4) Amanat Undang - Undang No. 23 Tahun 2002 tentang Perlindungan Anak Bab III, Pasal 50 (LPA, 2006) menegaskan bahwa pendidikan diarahkan pada :

a) Pengembangan sikap dan kemampuan kepribadian anak, bakat kemampuan mental dan fisik sampai mencapai potensi mereka yang optimal

b) Pengembangan penghormatan atas hak asasi manusia dan kebebasan asasi

c) Pengembangan rasa hormat terhadap orang, identitas budaya, bahasa dan nilainilainya sendiri, nilai-nilai nasional dimana anak bertempat 
tinggal, darimana anak berasal, peradaban-peradaban yang berbeda dari peradaban sendiri

d) Persiapan anak untuk kehidupan yang bertanggung-jawab

e) Pengembangan rasa hormat dan cinta lingkungan hidupnya.

Khusus di TK bahan ajar yang dimaksud adalah tema. Tema merupakan pusat pembelajaran. Tema merupakan alat/sarana atau wadah untuk mengenalkan berbagai konsep kepada anak-anak. Tema diberikan dengan tujuan (1) menyatukan isi kurikulum dalam satu kesatuan yang utuh. (2) jika pembelajaran dilakukan dengan memanfaatkan tema, maka pemilihan tema dalam kegiatan pembelajaran hendaknya dikembangkan melalui hal - hal yang paling dekat dengan anak, sederhana, serta menarik minat anak. Penggunaan tema dimaksudkan agar anak mampu mengenal berbagai konsep secara mudah dan jelas.

Ki Hajar Dewantara mengatakan bahwa pelajaran kebangsaan yang memang kodrati pada taman anak harus mengajarkan : a) permainan dan olah raga dengan nyanyian anak-anak dan tari (pemeliharaan badan secara ritmis), b) nyanyian-nyanyian daerah, menggambar corak dan warna, ketrampilan (menganyam, merangkai bunga) dengan menggunakan bahan-bahan lokal, misal: daun pisang, janur. dll. Sebagai latihan untuk kesempurnaan panca indera dihubungkan dengan rasa; c) ceritera yang berwujud dongeng (ceritera daerah) yang dihubungkan dengan pelajaran bahasa dan lagu, d) pelajaran mengenal keadaan tempat kelilingnya si anak untuk mempersiapkan pengetahuan IPA, IPS dan Ilmu Kenegaraan. Berdasarkan beberapa pendapat tersebut di atas, perlu adanya buku panduan dan penuntun alat permainan 
yang mempermudah dan membantu guru dalam menyampaikan nilai-nilai kebangsaan kepada anak TK.

c. Wawasan Kebangsaan

Wawasan kebangsaan lahir ketika bangsa Indonesia berjuang membebaskan diri dari segala bentuk penjajahan, seperti penjajahan oleh Portugis, Belanda, Inggris, dan Jepang. Perjuangan bangsa Indonesia yang waktu itu masih bersifat lokal ternyata tidak membawa hasil, karena belum adanya persatuan dan kesatuan, sedangkan di sisi lain kaum colonial terus menggunakan politik "devide et impera". Kendati demikian, catatan sejarah perlawanan para pahlawan itu telah membuktikan kepada kita tentang semangat perjuangan bangsa Indonesia yang tidak pernah padam dalam usaha mengusir penjajah dari Nusantara.

Dalam perkembangan berikutnya, muncul kesadaran bahwa perjuangan yang bersifat nasional, yakni perjuangan yang berlandaskan persatuan dan kesatuan dari seluruh bangsa Indonesia akan mempunyai kekuatan yang nyata. Kesadaran tersebut kemudian mendapatkan bentuk dengan lahirnya pergerakan Budi Utomo pada tanggal 20 Mei 1908 yang merupakan tonggak awal sejarah perjuangan bangsa yang bersifat nasional itu, yang kemudian disusul dengan lahirnya gerakan-gerakan kebangsaan di bidang politik, ekonomi/perdagangan, pendidikan, kesenian, pers dan kewanitaan.

Tekad perjuangan itu lebih tegas lagi dengan Sumpah Pemuda 28 Oktober 1928 dengan ikrar "Satu Nusa, Satu Bangsa, dan menjunjung tinggi bahasa persatuan bahasa Indonesia". Wawasan kebangsaan tersebut 
kemudian mencapai satu tonggak sejarah, bersatu padu memproklamasikan kemerdekaan pada tanggal 17 Agustus 1945.

Dalam perjalanan sejarah itu telah timbul pula gagasan, sikap, dan tekad yang bersumber dari nilai-nilai budaya bangsa serta disemangati oleh cita-cita moral rakyat yang luhur. Sikap dan tekad itu adalah pengejawantahan dari satu Wawasan Kebangsaan.

1) Pengertian Wawasan Kebangsaan

Istilah Wawasan Kebangsaan terdiri dari dua suku kata yaitu "Wawasan” dan “Kebangsaan”. Dalam Kamus Besar Bahasa Indonesia (2002) dinyatakan bahwa secara etimologis istilah “wawasan" berarti: (1) hasil mewawas, tinjauan, pandangan dan dapat juga berarti (2) konsepsi cara pandang. Wawasan Kebangsaan sangat identik dengan Wawasan Nusantara yaitu cara pandang bangsa Indonesia dalam mencapai tujuan nasional yang mencakup perwujudan Kepulauan Nusantara sebagai kesatuan politik, sosial budaya, ekonomi dan pertahanan keamanan (Suhady dan Sinaga, 2006).

"Kebangsaan" berasal dari kata "bangsa" yang menurut Kamus Besar Bahasa Indonesia (2002) berarti kelompok masyarakat yang bersamaan asal keturunan, adat, bahasa, dan sejarahnya, serta berpemerintahan sendiri. Sedangkan "kebangsaan" mengandung arti (1) ciri-ciri yang menandai golongan bangsa, (2) perihal bangsa; mengenai (yang bertalian dengan) bangsa, (3) kesadaran diri sebagai warga dari suatu negara. 
Dengan demikian wawasan kebangsaan dapat diartikan sebagai konsepsi cara pandang yang dilandasi akan kesadaran diri sebagai warga dari suatu negara akan diri dan lingkungannya di dalam kehidupan berbangsa dan bernegara . Prof. Muladi, Gubernur Lemhannas RI, meyampaikan bahwa wawasan kebangsaan adalah cara pandang bangsa Indonesia mengenai diri dan lingkungannya, mengutamakan kesatuan dan persatuan wilayah dalam penyelenggaraan kehidupan bermasyarakat, berbangsa dan bernegara . Kesatuan atau integrasi nasional bersifat kultural dan tidak hanya bernuansa struktural mengandung satu kesatuan ideologi, kesatuan politik, kesatuan sosial budaya, kesatuan ekonomi, dan kesatuan pertahanan dan keamanan.

Wawasan kebangsaan menentukan cara bangsa mendayagunakan kondisi geografis negara, sejarah, sosio-budaya, ekonomi dan politik serta pertahanan keamanan dalam mencapai cita-cita dan menjamin kepentingan nasional. Wawasan kebangsaan menentukan bangsa menempatkan diri dalam tata berhubungan dengan sesama bangsa dan dalam pergaulan dengan bangsa lain di dunia internasional. Wawasan kebangsaan mengandung komitmen dan semangat persatuan untuk menjamin keberadaan dan peningkatan kualitas kehidupan bangsa dan menghendaki pengetahuan yang memadai tentang tantangan masa kini dan masa mendatang serta berbagai potensi bangsa.

Wawasan kebangsaan dapat juga diartikan sebagai sudut pandang atau cara memandang yang mengandung kemampuan seseorang atau kelompok orang untuk memahami keberadaan jati diri sebagai suatu 
bangsa dalam memandang dirinya dan bertingkah laku sesuai falsafah hidup bangsa dalam lingkungan internal dan lingkungan eksternal.

Dengan demikian dalam kerangka NKRI, wawasan kebangsaan adalah cara kita sebagai bangsa Indonesia di dalam memandang diri dan lingkungannya dalam mencapai tujuan nasional yang mencakup perwujudan Kepulauan Nusantara sebagai kesatuan politik, sosial budaya, ekonomi dan pertahanan keamanan, dengan berpedoman pada falsafah Pancasila dan UUD 1945 atau dengan kata lain bagaimana kita memahami Wawasan Nusantara sebagai satu kesatuan POLEKSOSBUD dan HANKAM.

2) Wawasan Kebangsaan Indonesia

Konsep kebangsaan merupakan hal yang sangat mendasar bagi bangsa Indonesia. Dalam kenyataannya konsep kebangsaan itu telah dijadikan dasar negara dan ideologi nasional yang terumus di dalam Pancasila sebagaimana terdapat dalam Alinea IV Pembukaan UUD 1945. Konsep kebangsaan itulah yang membedakan bangsa Indonesia dengan bangsa-bangsa lain di dunia ini.

Dorongan yang melahirkan kebangsaan kita bersumber dari perjuangan untuk mewujudkan kemerdekaan, memulihkan martabat kita sebagai manusia. Wawasan kebangsaan Indonesia menolak segala diskriminasi suku, ras, asal-usul, keturunan, warna kulit, kedaerahan, golongan, agama dan kepercayaan kepada Tuhan Yang Maha Esa, kedudukan maupun status sosial. Konsep kebangsaan kita bertujuan membangun dan mengembangkan persatuan dan kesatuan. 
Dalam zaman Kebangkitan Nasional 1908 yang dipelopori oleh Budi Utomo menjadi tonggak terjadinya proses Bhineka Tunggal Ika. Berdirinya Budi Utomo telah mendorong terjadinya gerakan-gerakan atau organisasi-organisasi yang sangat majemuk, baik di pandang dari tujuan maupun dasarnya.

Dengan Sumpah Pemuda, gerakan Kebangkitan Nasional, khususnya kaum pemuda berusaha memadukan kebhinnekaan dengan ketunggalikaan. Kemajemukan, keanekaragaman seperti suku bangsa , adat istiadat, kebudayaan, bahasa daerah, agama dan kepercayaan terhadap Tuhan Yang Maha Esa tetap ada dan dihormati.

Wawasan kebangsaan Indonesia tidak mengenal adanya warga negara kelas satu, kelas dua, mayoritas atau minoritas. Hal ini antara lain dibuktikan dengan tidak dipergunakannya bahasa Jawa misalnya, sebagai bahasa nasional tetapi justru bahasa melayu yang kemudian berkembang menjadi bahasa Indonesia.

Derasnya pengaruh globalisasi, bukan mustahil akan memporak porandakan adat budaya yang menjadi jati diri kita sebagai suatu bangsa dan akan melemahkan paham nasionalisme. Paham nasionalisme adalah suatu paham yang menyatakan bahwa loyalitas tertinggi terhadap masalah duniawi dari setiap warga bangsa ditunjukan kepada negara dan bangsa.

Meskipun dalam awal pertumbuhan nasionalisme diwarnai oleh slogan yang sangat terkenal, yaitu: liberty, equality, fraternality, yang merupakan pangkal tolak nasionalisme yang demokratis, namun dalam 
perkembangannya nasionalisme pada setiap bangsa sangat diwarnai oleh nilai-nilai dasar yang berkembang dalam masyarakatnya masing-masing, sehingga memberikan ciri khas bagi masing-masing bangsa.

Wawasan kebangsaan Indonesia menjadikan bangsa yang tidak dapat mengisolasi diri dari bangsa lain yang menjiwai semangat bangsa bahari yang terimplementasikan menjadi wawasan nusantara bahwa wilayah laut Indonesia adalah bagian dari wilayah negara kepulauan yang diakui dunia. Wawasan kebangsaan merupakan pandangan yang menyatakan negara Indonesia merupakan satu kesatuan dipandang dari semua aspek sebagai pandangan hidup bangsa Indonesia dalam mendayagunakan konstelasi Indonesia, sejarah dan kondisi sosial budaya untuk mengejawantahan semua dorongan dan rangsangan dalam usaha mencapai perwujudan aspirasi bangsa dan tujuan nasional yang mencakup kesatuan politik, kesatuan sosial budaya, kesatuan ekonomi, kesatuan pertahanan keamanan.

Wawasan kebangsaan Indonesia yang menjadi sumber perumusan kebijakan desentralisasi pemerintahan dan pembangunan dalam rangka pengembangan otonomi daerah harus dapat mencegah disintegrasi / pemecahan negara kesatuan, mencegah merongrong wibawa pemerintah pusat, mencegah timbulnya pertentangan antara pemerintah pusat dengan pemerintah daerah. Melalui upaya tersebut diharapkan dapat terwujud pemerintah pusat yang bersih dan akuntabel dan pemerintah daerah yang tumbuh dan berkembang secara mandiri dengan daya saing yang sehat antar daerah dengan terwujudnya kesatuan 
ekonomi, kokohnya kesatuan politik, berkembangnya kesatuan budaya yang memerlukan warga bangsa yang kompak dan bersatu dengan ciri kebangsaan, netralitas birokrasi pemerintahan yang berwawasan kebangsaan, sistem pendidikan yang menghasilkan kader pembangunan berwawasan kebangsaan.

Wawasan kebangsaan Indonesia memberi peran bagi bangsa Indonesia untuk proaktif mengantisipasi perkembangan lingkungan stratejik dengan memberi contoh bagi bangsa lain dalam membina identitas, kemandirian dan menghadapi tantangan dari luar tanpa konfrontasi dengan meyakinkan bangsa lain bahwa eksistensi bangsa merupakan aset yang diperlukan dalam mengembangkan nilai kemanusiaan yang beradab.

Akhirnya, bagi bangsa Indonesia, untuk memahami bagaimana wawasan kebangsaan perlu memahami secara mendalam falsafah Pancasila yang mengandung nilai-nilai dasar yang akhirnya dijadikan pedoman dalam bersikap dan bertingkah laku yang bermuara pada terbentuknya karakter bangsa.

3) Makna Wawasan Kebangsaan

Wawasan Kebangsaan bagi bangsa Indonesia memiliki makna:

Wawasan kebangsaan mengamanatkan kepada seluruh bangsa agar menempatkan persatuan, kesatuan, serta kepentingan dan keselamatan bangsa dan negara di atas kepentingan pribadi atau golongan; 
Wawasan kebangsaan mengembangkan persatuan Indonesia sedemikian rupa sehingga asas Bhinneka Tunggal Ika dipertahankan;

Wawasan kebangsaan tidak memberi tempat pada patriotisme yang licik;

Dengan wawasan kebangsaan yang dilandasi oleh pandangan hidup Pancasila, bangsa Indonesia telah berhasil merintis jalan menjalani misinya di tengah-tengah tata kehidupan di dunia;

NKRI yang merdeka, bersatu, berdaulat, adil dan makmur bertekad untuk mewujudkan bangsa yang maju dan mandiri serta sejahtera lahir batin, sejajar dengan bangsa lain yang sudah maju.

4) Nilai Dasar Wawasan Kebangsaan

Nilai Wawasan Kebangsaan yang terwujud dalam persatuan dan kesatuan bangsa memiliki enam dimensi yang bersifat mendasar dan fundamental, yaitu:

- Penghargaan terhadap harkat dan martabat manusia sebagai makhluk ciptaan Tuhan Yang Maha Esa;

- Tekad bersama untuk berkehidupan kebangsaan yang bebas, merkeka, dan besatu;

- Cinta akan tanah air dan bangsa;

- Demokrasi atau kedaulatan rakyat;

- Kesetiakawanan sosial;

- Masyarakat adil-makmur. 


\section{Dampak model pendidikan berwawasan nusantara bagi anak usia dini} sebagai sarana intregasi bangsa

"Menanamkan wawasan kebangsaan kepada anak usia dini sangat bermanfaat dalam membentuk karakter anak. Pembekalan wawasan kebangsaan dapat dimulai pada pendidikan anak usia dini. Usia 0-6 tahun adalah usia emas bagi pertumbuhan dan perkembangan anak," kata Sutjipto.

Model pendidikan berwawasan kebangsaan berpengaruh positif untuk membentuk prilaku anak usia dini, sehinggah memiliki karakter kebangsaan hinggah trcapainya ketahanan pribadi anak. Serta dapat mengembangkan sikap nasionalisme dalam menghadapi era globalisasi. Dan pendidikan berwawasan kebangsaan ini dihrapkan dapat mempersiapkan mereka kelak sebagai manusiamanusia yang mempunyai identitas di dalam masyarakat lokal, sekaligus mempunyai visi untuk membangun dunia bersama budaya global. Pengaruh positif tersebut diantaranya :

a. mengembangkan sikap dan kemampuan kepribadian anak, bakat kemampuan mental dan fisik sampai mencapai potensi mereka yang optimal

b. mengembangkan penghormatan atas hak asasi manusia dan kebebasan asasi

c. mengembangkan rasa hormat terhadap orang, identitas budaya, bahasa dan nilainilainya sendiri, nilai-nilai nasional dimana anak bertempat tinggal, darimana anak berasal, peradaban-peradaban yang berbeda dari peradaban sendiri

d. Mepersiapkan anak untuk kehidupan yang bertanggung-jawab

e. Mengembangkan rasa hormat dan cinta lingkungan hidupnya 


\section{KESIMPULAN}

Berdasarkan hasil analisis di atas, terdapat beberapa kesimpulan yang dapat ditarik terkait dengan model pendidikan berwawasan kebangsaan pada anak usia dini berikut ini :

1. Tema adalah salah satu cara yg digunakan dalam model pembelajaran di TK, dengan tema inilah berbagai macam potensi anak dapat dikembangkan seperti, fisik motorik, keterampilan, kognitif, sains, bahasa, seni, sosial dan emosional serta nilai-nilai keagamaan,moral dan nilai-nilai kebangsaan.

2. Dunia anak adalah dunia bermain. Bermain untuk anak sesungguhnya sebuah proses belajar. Anak-anak belajar nilai-nilai kebangsaan melalui pengalaman bermain. Dengan suasana yang menyenangkan dan rekreatif nilai-nilai kebangsaan disosialisasikan dan ditransformasikan kepada anak, sehingga proses pendidikan yang dilaksanakan tidak bersifat indoktrinasi atau pemaksaan.

3. Perlu tema-tema yang menarik terkait dengan konsep-konsep wawasan nusantara sebagai wawasan kebangsaan diberikan kepada anak TK.

\section{SARAN}

Model tematik intregatir pendidikan berwawasan kebangsaan pada anak usia dini melalui pembelajaran di TK merupakan salah satu model pada jalur pendidikan formal (sekolah), oleh karena itu masi dapat dikembangkan model alternative lain melalui jalur pendidikan informal (keluarga) dan pendidikan anak usia dini non formal ( Kelompok bermain, Taman penitipan Anak, Pos PAUD). 


\section{REFERENSI}

Borg, Walter R. \& Gall, Meredith D. 1983. Educational Research: An Introduction. New York, London: Longman.

Choirul Mahfud. 2006. Pendidikan Multikultural. Yogyakarta: Pustaka Pelajar Convention on the Rights of the Child . 1990. Konvensi Hak-hak Anak. Unicef.

Departemen Pendidikan Nasional. 2004. Direktorat Jenderal Pendidikan Dasar dan Menengah. Kurikulum TK dan RA. Standar Kompetensi. Jakarta : Direktorat Pendidikan TK dan SD.

Ki Hadjar Dewantara. 2009. Pendidikan: Bagian Pertama. Yogyakarta : Majelis Luhur Persatuan Taman Siswa.

L Andriani P dan Ariefa E. 2016. Model pendidikan. Yogyakarta : Pustaka Pelajar.

Lembaga Perlindungan Anak DIY. 2006. Undang-undang Republik Indonesia Nomor 23 Tahun 2002 tentang Perlindungan Anak.

Mayke Sugianto. 1995. Bermainan, Mainan, dan Permainan Anak Usia Dini. Jakarta: Departemen Pendidikan dan Kebudayaan Direktorat Jenderal Pendidikan Tinggi.

Noor M Bakry. 1994. Pancasila Yuridis Kenegaraan, Yogyakarta : Liberty.

Slamet Suyanto. 2005. Dasar-dasar Pendidikan Anak Usia Dini. Yogyakarta : Hikayat Publishing.

Sudono Anggani. 1992. Sumber Belajar dan Permainan Anak Usia Dini. Jakarta : Grasindo.

Suhady, Idup dan A.M. Sinaga. 2006. Wawasan Kebangsaan Dalam Kerangka Negara Kesatuan Republik Indonesia, Lembaga Administrasi Negara RI. Jakarta.

Sunarso dkk. 2008. Pendidikan Kewarganegaraan. Yogyakarta : UNY Press.

Yayasan Amal Bhakti Ibu. 2005. Anak Indonesia Membangun Budaya Damai. Jakarta. 